\title{
Research on Chinese New Energy Vehicles Based on Ecological View
}

\author{
Xiaohui $\mathrm{Su}^{1 *}$, Kaining Meng ${ }^{2}$ and $\mathrm{Di} \mathrm{Liu}^{3}$ \\ ${ }^{1}$ School of Art and Design, Xihua University, Chengdu, Sichuan, 610039, China \\ ${ }^{2}$ School of Art and Design, Xihua University, Chengdu, Sichuan, 610039, China \\ ${ }^{3}$ School of Art and Design, Xihua University, Chengdu, Sichuan, 610039, China
}

\begin{abstract}
This article studies and discusses the existing problems and future development of Chinese new energy vehicles from the perspective of ecological view proposed by General Secretary Xi Jinping. Through data collection and data analysis, this paper summarizes the current problems of short-range mileage, difficult battery recycling, and environmental pollution caused by the current domestic new energy vehicles. Improve domestic new energy vehicle companies from three aspects: car building technology, battery recycling, and service experience, protect the ecological environment, increase economic competitiveness, and promote sustainable economic and social development.
\end{abstract}

\section{Introduction}

New energy vehicles are one of Chinese strategic emerging industries. Since China officially launched the
"863" plan in 2001 as a major special project for electric vehicles, Chinese new energy vehicle industry has grown by more than 1 million units in the past 20 years, ranking first in the world.

Table 1. Xi Jinping ecological view.

\begin{tabular}{ll}
\hline Four dimensions & Content \\
\hline Ecological Civilization View & Shaping people and nature in harmony. \\
Ecological Economy View & Promote the coordinated development of economy and ecology. \\
Ecological Security View & Carry forward the idea of rule of law and red line thinking. \\
Ecological Livelihood View & Good ecological environment is the well-being of people. \\
\hline
\end{tabular}

However, Chinese new energy vehicles still have many problems such as difficulties in battery recycling, short vehicle range, false environmental protection, etc. This article is based on Xi Jinping ecological view (Table 1), researches and discusses the existing problems and future development of Chinese new energy vehicles, proposes corresponding improvement directions, enhances economic competitiveness, and promotes ecological sustainable development of new energy vehicles.

\section{Existing problems of domestic new energy vehicles}

Electric vehicles are not strictly new energy vehicles. They appeared in 1873, 13 years earlier than fuel vehicles (Figure 1). At present, the main new energy vehicles in the Chinese market are electric vehicles that use batteries as a source of power. These domestic new energy vehicles have three main problems: pollution of the environment, short range and difficult battery recycling.

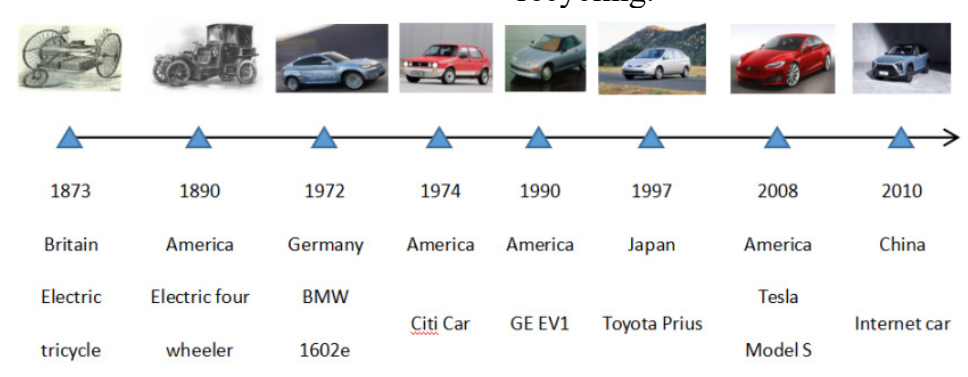

Figure 1. The history of the world's electric vehicles.

\footnotetext{
*Corresponding author's e-mail: 1163479373@qq.com
} 


\subsection{New energy vehicles battery life issues}

At present, most of the power batteries used in new energy vehicles are lithium-ion batteries. The best operating temperature for lithium batteries is $25^{\circ} \mathrm{C}$. At low temperatures, the activity of the positive and negative electrode materials in the lithium-ion battery will decrease, the number of ions that the lithium ions move in the battery solution will become less and less,

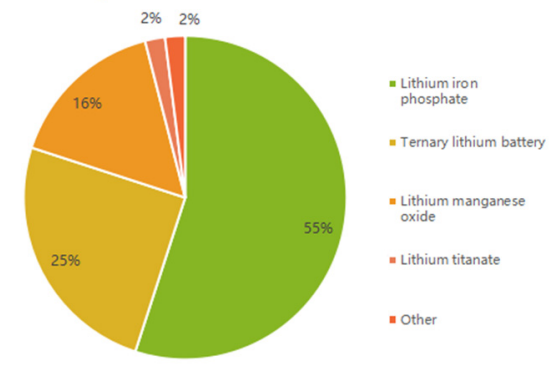

Figure 2. China new energy vehicle power battery classification.

\subsection{New energy automotive battery recycling issues}

As shown in Figure 2, various lithium batteries occupy almost all new energy vehicle markets, of which lithium iron phosphate is $55 \%$ and ternary lithium batteries are $25 \%$. When the capacity of the lithium battery decays to the initial capacity, $60 \%-80 \%$, it needs to be replaced. The average life of lithium iron phosphate power battery is 4-6 years, and the ternary material power battery is $2-4$ years (Figure 3). Most power batteries need to be replaced and recycled in about 4 years. At present, there are many types of household power batteries, the structure of the battery pack is not uniform, and the recycling cost of lithium batteries is high. However, domestic recycling companies are small in scale, the level of recycling technology is not high, and the recovery of power batteries is difficult.

\subsection{New Energy Vehicle Pollution issues}

New energy vehicles have been promoted for environmental protection. In fact, electricity is a secondary energy source. Part of the energy will be lost during the conversion process, unable to reach the $90 \%$ conversion rate specified in the promotion, or even lower than the energy efficiency of some gasoline vehicles. At present, the energy density of power batteries used in the market is too low, much lower than the density of gasoline. New energy vehicles only convert direct emissions to indirect emissions, and the pollutant discharge sites are transferred from cities to power plants. Moreover, the toxic substances in lithium batteries will not only damage the nervous system and hematopoietic functions of the human body, cause cancer, and even 20 grams of lithium batteries can pollution of 1 square kilometer of land for about 50 years will cause immeasurable pollution to the environment. and the capacity of the lithium battery will decrease by about $1 \%$ per $1{ }^{\circ} \mathrm{C}$. In winter, the power battery of new energy vehicles is affected by temperature, and the mileage is shortened. In addition to the large amount of electrical energy required for heating, the mileage will also decrease with the consumption of electrical energy, which will cause the battery life of new energy vehicles to fall short of publicity standards.

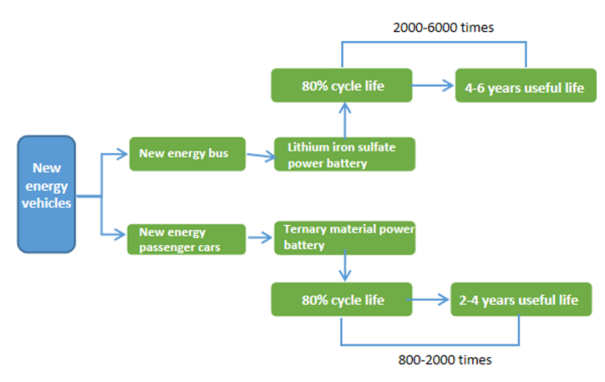

Figure 3. New energy vehicle lithium battery life.

\section{Lower national subsidies lead to lower sales of domestic new energy vehicles}

Chinese electric vehicle subsidies were 59 billion yuan in 2015 and 83 billion yuan in 2016. During the "13th Five-Year Plan", the central government subsidies for new energy vehicles were 390 billion yuan. Driven by high subsidies, NIO, WELTMEISTER, XPENG and many domestic new energy automobile companies emerged. After reducing state subsidies, due to weak industrial accumulation, insufficient technical reserves, false publicity, and huge potential safety hazards, joint ventures by domestic new energy automobile companies are more difficult and car sales are lower (Table 2). 
Table 2. Domestic cumulative sales of electric vehicles (2019, 1.1-9.30) (unit: vehicles).

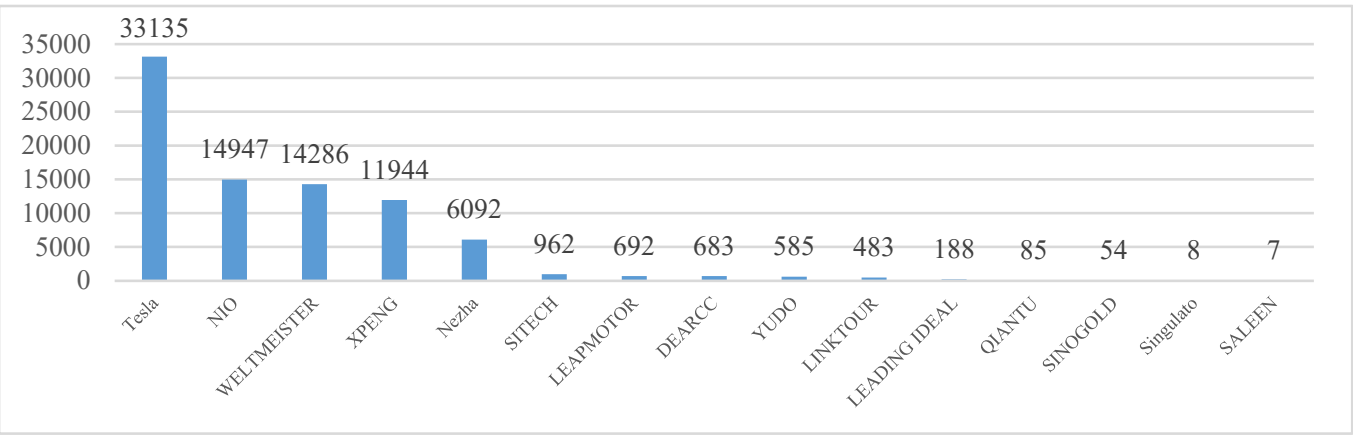

\section{The development direction of domestic new energy vehicle companies}

Based on the current problems of domestic new energy vehicles, the joint venture between domestic new energy vehicle companies is difficult and the sales of new energy vehicles continue to decline. In order to improve the market competitiveness of domestic new energy vehicle companies, improvements can be made from three aspects: car building technology, battery recycling, and service experience.

\subsection{Improve car building technology, accelerate intelligent network connectivity and reduce costs}

Domestic new energy vehicle companies should work hard to improve vehicle manufacturing technology, accelerate new energy vehicle intelligent network connection empowerment, and reduce the cost of new energy vehicle production, thereby reducing safety risks, increasing the mileage of new energy vehicles, their economics, new energy vehicle sales and the proportion of new energy vehicles in the automotive market, and accelerating the replacement of fuel vehicles.

\subsection{Eliminate false publicity and reasonably recycle and dispose of batteries}

Eliminate all kinds of false publicity, do not promote it to consumers with environmental friendliness as a gimmick, use lithium battery recycling costs as one of the key indicators of vehicle performance evaluation, rationally recycle and dispose of batteries, and reduce the driving of new energy vehicles and contamination after the battery is discarded.

\subsection{Take advantage of local advantages and improve service experience}

Utilize domestic advantages such as domestic new energy automobile companies to be more familiar with local consumer preferences, better industrial chain layout, and improved after-sales service systems to provide consumers with a better experience and service, improve
(Source: China Insurance Regulatory Commission) consumer service experience and satisfaction, increase the market Competitiveness and occupy more market share.

\section{Conclusion}

This article is based on $\mathrm{Xi}$ Jinping ecological view. Through data collection and data analysis, this paper finds false propaganda of new energy vehicles inside, analyzes the current domestic new energy vehicles mileage, difficulties in battery recycling, and pollution of the environment. With the reduction of state subsidies and the increasingly difficult joint venture of domestic new energy automobile companies, the corresponding improvement directions are proposed from the aspects of automobile manufacturing technology, battery recycling and service experience, in order to improve economic competitiveness and promote the development of new energy vehicles.

\section{References}

1 Luo, H.J., Xu, M.J. (2018) Four Basic Dimensions of Jinping's Ecological View and Contemporary Implications. J. Journal of Central South University of Forestry and Technology (Social Science Edition)., $12(02): 1-5+18$.

2 Hao, J.Y. (2015) Present situation and prospect analysis of natural gas vehicle. J. Journal of Anyang Institute of Technology., 14 (04): 33-34.

3 Zhao, S.X. , Guo, S.T. , Zhao, J.W. (2016) Development on low-temperature performance of lithium ion batteries. J. Journal of the Chinese Ceramic Society., 44 (1): 19-28.

$4 \mathrm{Wu}, \mathrm{F}$. (2018) Don't rush into power batteries for quick success and industry development depends on the market. J. Inverter World., (07): 61-62.

5 Liu, Z.Z., Chen, J., Lin, K., Zhao, Y.J., Xu, H.P. (2015) Development status and trends of electric vehicles at home and abroad. J. Electric Power Construction., 36 (07): 25-32.

6 Wei, X.Z., Xu, W., Shen, D. (2009) Identification of internal resistance of lithium ion battery and its application in life estimation. J. Power Source Technology., 3 (10): 217-220. 